\title{
Clofarabine/busulfan-based reduced intensity conditioning regimens provides very good survivals in acute myeloid leukemia patients in complete remission at transplant: a retrospective study on behalf of the SFGM-TC
}

\author{
Amandine Le Bourgeois ${ }^{1}$, Myriam Labopin ${ }^{2}$, Mathieu Leclerc ${ }^{3}$, Régis Peffault \\ de Latour ${ }^{4}$, Jean-Henri Bourhis ${ }^{5}$, Patrice Ceballos ${ }^{6}$, Corentin Orvain?, Hélène \\ Labussière Wallet ${ }^{8}$, Karin Bilger ${ }^{9}$, Didier Blaise ${ }^{10}$, Marie-Thérese Rubio ${ }^{11}$, Thierry \\ Guillaume $^{1}$, Mohamad Mohty ${ }^{2}$, Patrice Chevallier ${ }^{1}$ and on behalf of Société \\ Francophone de Greffe de Moelle et de Thérapie Cellulaire \\ ${ }^{1}$ Department of Hematology, CHU Hôtel Dieu, Nantes, France \\ ${ }^{2}$ Department of Hematology, Hôpital Saint Antoine, Paris, France \\ ${ }^{3}$ Department of Hematology, Hôpital Henri Mondor, Créteil, France \\ ${ }^{4}$ Department of Hematology, Hôpital Saint Louis, Université Paris 7, Denis Diderot, Paris, France \\ ${ }^{5}$ Department of Hematology, Hôpital Gustave Roussy, Paris, France \\ ${ }^{6}$ Department of Hematology, CHU de Montpellier, Montpellier, France \\ ${ }^{7}$ Department of Hematology, CHU d'Angers, Angers, France \\ ${ }^{8}$ Department of Hematology, Centre Hospitalier Lyon Sud, Lyon, France \\ ${ }^{9}$ Department of Hematology, CHU Strasbourg, Strasbourg, France \\ ${ }^{10}$ Department of Hematology, Centre de Recherche en Cancérologie de Marseille, Institut Paoli Calmettes, Marseille, France \\ ${ }^{11}$ Department of Hematology, CHU Nancy, Nancy, France \\ Correspondence to: Amandine Le Bourgeois, email: amandine.lebourgeois@chu-nantes.fr \\ Patrice Chevallier, email: patrice.chevallier@chu-nantes.fr \\ Keywords: allogeneic stem cell transplantation; clofarabine; busulfan; reduced intensity conditioning regimen; acute myeloid leukemia \\ Received: August 24, $2018 \quad$ Accepted: November 01, $2018 \quad$ Published: November 27, 2018 \\ Copyright: Bourgeois et al. This is an open-access article distributed under the terms of the Creative Commons Attribution License \\ 3.0 (CC BY 3.0), which permits unrestricted use, distribution, and reproduction in any medium, provided the original author and \\ source are credited.
}

\section{ABSTRACT}

Background: Clofarabine has been proved to have higher anti-leukemic myeloid activity compared to fludarabine, a drug extensively used as part of reduced intensity conditioning (RIC) for allogeneic stem cell transplantation (allo-SCT).

Results: Eighty-four patients were included. The majority of patients had acute myeloid leukemia (AML, $n=63$ ). Sixty-one patients were in complete remission (AML $n=55$ ). With a median follow up of 31 months (range: 5.7-74.1), 2-year overall (OS) and disease-free (DFS) survivals, relapse incidence (RI), non-relapse mortality (NRM) and graft-versus-host disease (GVHD)/relapse free survival (GRFS) were $\mathbf{6 4 . 5 \%}$ (53.8-75.2); 57.2\% (46.2-68.2); 27.7\% (18.2-37.9); $15.1 \%(8.2-23.9)$ and $43.6 \%$ (32.5-54.7), respectively. Considering AML in remission, 2-year OS, DFS, RI, NRM and GRFS were $74.2 \%$ (62-86.5); $66.8 \%$ (53.6-79.9); $23.4 \%(12.7-36) ; 9.8 \%$ (3.5-19.9) and 50.9\% (36.9-64.9), respectively. Two-year outcomes were similar between CloB2A1 and CloB2A2 sub-groups. In multivariate analysis, active disease at transplant was the only factor adversely impacting 2 years outcomes.

Conclusions: CloB2A2/A1 RIC regimen provides very good results for AML patients allografted in CR and could be retained as a new RIC platform for these patients. 


\begin{abstract}
Materials and Methods: This was a retrospective study including all patients who received a clofarabine/busulfan based RIC allo-SCT for myeloid malignancies and reported within the SFGM-TC registry. RIC regimen consisted of clofarabine $30 \mathbf{~ m g} /$ $\mathrm{m}^{2} /$ day 4 to 5 days (Clo), busulfan $3.2 \mathrm{mg} / \mathrm{kg} /$ day 2 days (B2) and $2.5 \mathrm{mg} / \mathrm{kg} / \mathrm{day}$ of rabbit anti-thymocyte globulin 1 or 2 days (A1 or A2). The primary objective of the study was to report the main outcomes of the whole cohort at 2 years.
\end{abstract}

\section{INTRODUCTION}

Reduced-intensity conditioning regimens (RIC) were successfully introduced twenty years ago to decrease the toxicity of myeloablative allogeneic stem cell transplantation (allo-SCT). This resulted in the doubling of the number of allo-SCT performed each year, because older patients and those with comorbidities could tolerate such a procedure [1-7]. The FB2A2 regimen (fludarabine 30 $\mathrm{mg} / \mathrm{kg} /$ day for 5 days, busulfan $3.2 \mathrm{mg} / \mathrm{kg} / \mathrm{d}$ iv for 2 days, and rabbit anti-thymocyte globulin (ATG) $2.5 \mathrm{mg} / \mathrm{kg} / \mathrm{d}$ for 2 days) was rapidly established as one of the standards of care for RIC regimen in Europe, especially in France [4-9].

As relapse remains as one of the main causes of morbidity and mortality after allo-SCT, strategies to improve outcomes of patients were developed thereafter, including modification of the conditioning regimen using the same drugs at higher dose (reduced-toxicity myeloablative conditioning regimen, FB3/FB4) [10-12] or other drugs with higher anti-leukemic activity. For the latter, clofarabine, a second-generation purine analogue, has been proven to have both anti-myeloid [13-15] and anti-lymphoid activity $[16,17]$. Recently, clofarabine (Clo) has been used as part of fludarabine-busulfan-based conditioning regimen instead of fludarabine, showing encouraging results. Thus, the CloB2A2 RIC regimen (clofarabine $30 \mathrm{mg} / \mathrm{kg} /$ day for 5 days, busulfan $3.2 \mathrm{mg} / \mathrm{kg} /$ day iv for 2 days, ATG $2.5 \mathrm{mg} / \mathrm{kg} /$ day for 2 days) has been validated in a prospective phase II study including 14 patients with acute lymphoblastic leukemia (ALL), 11 with acute myeloid leukemia (AML) and 5 with myelodysplastic syndrome (MDS). At one year, the overall survival (OS) and leukemia free survival (LFS) were of $63 \%$ and $57 \%$, respectively, and the non-relapse mortality (NRM) only of 3.3\%, suggesting a very good safety profile of the RIC regimen [18]. More intensive clofarabine/busulfan RIC regimens (CloB4) have also shown good safety profile after transplant for ALL [19]. Our group retrospectively compared the CloB2A2 $(n=39)$ versus FB2A2 $(n=316)$ RIC regimens in a cohort of patients with myeloid disease, and showed a significant OS benefit for the former in multivariate analysis [20].

The aim of the present study was to confirm the favorable impact of the CloB2A2 RIC regimen in a larger cohort of patients with myeloid malignancies. Also, because some centers decreased the dose of ATG
(CloB2A1) after 2014 with the aim to decrease relapse, [4] we also assessed the effect of this lower dose on outcomes.

\section{RESULTS}

\section{Characteristics of patients (Table 1)}

Between January 2008 and December 2016, 84 patients (males $n=47$, median age: 61.6 years) met the inclusion criteria. The outcomes of some patients have already been reported $[16,18]$. The majority of patients had AML $(n=63)$, including 43 cases in CR1, 12 in CR2 and 8 with active disease at transplant. According to ELNrisk classification [21], 7 AML cases were classified as favorable, 24 as intermediate-1, 8 as intermediate- 2 and 6 as unfavorable (unknown $n=18$ ). There were 21 patients with MDS $(n=18)$ or MPS $(n=3)$, including 6 in CR1 (all MDS) and 15 with active disease at transplant. All patients but one (bone marrow graft) received peripheral blood stem cell as graft source. All patients received cells from matched donors (sibling $n=34$; unrelated $n=50$ ).

There were no significant differences in terms of characteristics between CloB2A2 $(n=43$, median followup 39 months) and CloB2A1 ( $n=41$, median follow-up 21 months) patients, except for the median age of the cohort (65 vs 61 years, $p=0.02$ ), the dose of clofarabine ( $\geq 150$ $\mathrm{mg} / \mathrm{m} 2: 97.5 \%$ vs $49 \%$ of the patients, $p<0.001$ ), which were higher in the latter group and, as expected, the median year of transplant (2013 vs 2015, $p<0.001$ ) (Table 1). All patients engrafted except one CLOB2A1 case.

\section{Outcomes}

With a median follow up of 31 months (range: 5.7-74.1) for patients alive, the 2-year OS, LFS, RI, and NRM were $64.5 \%$ (53.8-75.2), $57.2 \%$ (46.2-68.2), $27.7 \%$ (18.2-37.9) and $15.1 \%(8.2-23.9)$, respectively. The CI of 100-day acute GVHD grade II-IV and III-IV were 20.2\% (12.4-29.4) and 7.1\% (2.9-14), respectively. The 2-year CI of extensive chronic GVHD was 9.6\% (4.1-17.8\%). The 2-year GRFS was $43.6 \%$ (32.5-54.7). The median time to relapse/progression from the transplant was 5.6 months (range: $0.59-31.5$ ). At last follow-up, 32 patients had died, mainly due to relapse $(n=17)$, then to GVHD $(n=6)$, infection $(n=6)$, hemorrhage $n=1$; microangiopathy $n=1$, and non-identified transplantrelated $n=1$. 
Table 1: Patients' characteristics

\begin{tabular}{|c|c|c|c|c|}
\hline & $\begin{array}{l}\text { Whole cohort } \\
\qquad N=84\end{array}$ & $\begin{array}{c}\text { CloB2A1 } \\
n=41\end{array}$ & $\begin{array}{c}\text { CloB2A2 } \\
n=43\end{array}$ & $p$-value \\
\hline Median follow-up: months (range) & $30.9(5.7-74.1)$ & $20.7(5.7-34.3)$ & $38.9(20.5-74.1)$ & \\
\hline Median year of transplant & $2014(09-16)$ & $2015(14-16)$ & $2013(09-16)$ & $<0.001$ \\
\hline Gender: males & $47(56 \%)$ & $25(61 \%)$ & $22(51 \%)$ & 0.36 \\
\hline $\begin{array}{l}\text { Median age at transplant: years } \\
\text { (range) }\end{array}$ & $61.6(20.6-73.9)$ & $65(24.6-73.9)$ & $60.8(20.6-71.1)$ & 0.028 \\
\hline $\begin{array}{l}\text { Diagnosis: } \\
\text { AML } \\
\text { MDS/MPS }\end{array}$ & $\begin{array}{l}63(75 \%) \\
21(25 \%)\end{array}$ & $\begin{array}{l}31(75.6 \%) \\
10(24.4 \%)\end{array}$ & $\begin{array}{l}32(74.4 \%) \\
11(25.6 \%)\end{array}$ & 0.9 \\
\hline $\begin{array}{l}\text { Status at transplant: } \\
\text { CR1 } \\
\text { CR2 } \\
\text { Active disease }\end{array}$ & $\begin{array}{l}49(58.3 \%) \\
12(14.3 \%) \\
23(27.4 \%)\end{array}$ & $\begin{array}{c}27(65.8 \%) \\
5(12.2 \%) \\
9(22 \%)\end{array}$ & $\begin{array}{l}22(51.2 \%) \\
7(16.3 \%) \\
14(32.5 \%)\end{array}$ & 0.39 \\
\hline Recipient CMV status: + & $40(48 \%)$ & $23(56 \%)$ & $17(39.5 \%)$ & 0.12 \\
\hline $\begin{array}{l}\text { Type of donor: } \\
\text { Gender: males } \\
\text { Sibling } \\
\text { MUD }\end{array}$ & $\begin{array}{c}52\left(62 \%^{\circ}\right. \\
34(40.5 \%) \\
50(59.5 \%)\end{array}$ & $\begin{array}{c}27(66 \%) \\
19(46.3 \%) \\
22(53.7 \%)\end{array}$ & $\begin{array}{l}25(58 \%) \\
15(34.9 \%) \\
28(65.1 \%)\end{array}$ & $\begin{array}{c}0.46 \\
0.285\end{array}$ \\
\hline CMV status: + & $24(29 \%)$ & $9(22 \%)$ & $15(35 \%)$ & 0.19 \\
\hline $\begin{array}{l}\text { Sex matching } \\
\text { Female } \rightarrow \text { Male } \\
\text { Others }\end{array}$ & $\begin{array}{l}13(15.5 \%) \\
71(84.5 \%)\end{array}$ & $\begin{array}{l}5(12.2 \%) \\
36(87.8 \%)\end{array}$ & $\begin{array}{c}8(18.6 \%) \\
35(81.4 \%)\end{array}$ & 0.47 \\
\hline $\begin{array}{l}\text { Stem-cell source } \\
\text { Bone Marrow } \\
\text { PBSC }\end{array}$ & $\begin{array}{c}1(1.2 \%) \\
83(98.8 \%)\end{array}$ & $\begin{array}{c}0(0 \%) \\
41(100 \%)\end{array}$ & $\begin{array}{c}1(2.3 \%) \\
42(97.7 \%)\end{array}$ & 0.33 \\
\hline $\begin{array}{l}\text { Previous transplant: } \\
\text { No } \\
\text { Previous allo-SCT } \\
\text { Previous auto-SCT }\end{array}$ & $\begin{array}{c}75(89.3 \%) \\
7(8.3 \%) \\
2(2.4 \%)\end{array}$ & $\begin{array}{c}39(95.1 \%) \\
2(4.9 \%) \\
0(0 \%)\end{array}$ & $\begin{array}{c}36(83.7 \%) \\
5(11.6 \%) \\
2(4.7 \%)\end{array}$ & 0.19 \\
\hline $\begin{array}{l}\text { GVHD prophylaxis: } \\
\text {-Csa } \\
\text {-Csa + MTX } \\
\text {-Csa + MMF }\end{array}$ & $\begin{array}{c}44(52.4 \%) \\
3(3.6 \%) \\
37(44 \%)\end{array}$ & $\begin{array}{c}18(43.9 \%) \\
0(0 \%) \\
23(56.1 \%)\end{array}$ & $\begin{array}{c}26(60.5 \%) \\
3(7 \%) \\
14(32.5 \%)\end{array}$ & 0.04 \\
\hline $\begin{array}{l}\text { Dose of clofarabine } \\
120 \mathrm{mg} / \mathrm{m}^{2} \\
\geq 150 \mathrm{mg} / \mathrm{m}^{2}\end{array}$ & $\begin{array}{l}23(27.3 \%) \\
61(72.7 \%)\end{array}$ & $\begin{array}{c}1(2.5 \%) \\
40(97.5 \%)\end{array}$ & $\begin{array}{l}22(51.2 \%) \\
21(48.8 \%)\end{array}$ & $<0.001$ \\
\hline
\end{tabular}

Abbreviations: AML: acute myeloid leukemia, MDS: myelodysplastic syndrome; MPS: myeloproliferative syndrome; CR: complete remission; BM: bone marrow, MUD: matched unrelated donor; CMV: cytomegalovirus; PBSC: peripheral blood stem cells; Allo-SCT: allogeneic stem cell transplant, Auto-SCT: autologous stem cell transplant; Csa: cyclosorine, MTX: methotrexate; MMF: mycophenolate mofetil.

Considering AML in CR $(n=55)$, the 2-year OS, LFS, RI, NRM and GRFS were 74.2\% (62-86.5); 66.8\% (53.6-79.9); 23.4\% (12.7-36); 9.8\% (3.5-19.9) and 50.9\% (36.9-64.9) respectively. The 100 day grade $2-4$ and $3-4$ acute GVHD CI were $16.4 \%$ (95\% CI: 8-27.3) and 1.8\% (95\% CI: 0.1-8.6), respectively, while the 2-year CI of extensive chronic GVHD was $10.4 \%$ (95\% CI: 3.7-21.2) (Figure 1).

\section{Univariate analysis}

In univariate analysis, active disease at transplant was associated with lower 2-year survivals (OS: 37.7\% [17.3-58.1] vs CR1: 75.5\% [62.8-88.2] vs CR2: 75\% [50.5-99.5], $p=0.001$; LFS: $31.8 \%$ [12.4-51.3] vs CR1: $69.9 \%$ [56.5-83.2] vs CR2: 58.3\% [30.4-86.2], $p=0.0004$; GRFS: $19.6 \%$ [2.1-37] vs CR1:53.9\% [39.1-68.7] 
vs CR2: $50 \%$ [21.7-78.3], $p=0.0006)$ and higher incidence of 2-year NRM (31.8\% [13.6-51.8] vs CR1: 9\% [2.8-19.8] vs CR2: $8.3 \%$ [0.4-32.4], $p=0.008)$. Also, older age (>median) was associated with better GRFS (56.3\% [40.3-72.3] vs 32.1\% [17.8-46.4], $p=0.03)$, while transplant from a MUD donor was associated with higher acute grade $2-4$ and 3-4 GVHD (28\% [16.3-40.9] vs 8.8\% [2.2-21.3], $p=0.04$; and $12 \%$ [4.8-22.7] vs $0 \%, p=0.03)$.

Finally, there were no differences in terms of 2-year outcomes between CloB2A1 and CloB2A2 subgroups considering the whole cohort (Table 2 and Figure 2) or only AML patients in CR (Table 2).

\section{Multivariate analysis}

In multivariate analysis, active disease at transplant was the only factor adversely impacting 2 year outcomes: OS: HR: 3.83 (95\% CI: 1.77-8.29, $p=0.0006$; DFS: 3.99; 95\% CI: 1.90-8.35, $p=0.0002$; GRFS: HR: 3.17; 95\% CI: 1.65-6.08, $p<0.0001$; relapse: HR: 2.60;
95\% CI: $1.00-6.77, p=0.04$; and NRM: HR: 7.02; 95\% CI: $2.02-24.36, p=0.002)$. Neither the conditioning regimen (CloB2A2 vs CloB2A1) nor the dose of clofarabine (120 mg/m² vs $\geq 150 \mathrm{mg} / \mathrm{m}^{2}$ ) influenced the outcomes.

\section{DISCUSSION}

Here, we have reported the largest retrospective cohort of patients allografted with a clofarabine/busulfanbased RIC regimen for myeloid malignancies. Although there are some biases common to all retrospective studies, very encouraging results have been observed with this platform, especially for AML cases in CR at transplant, as the 2 -year OS was almost $75 \%$ while LFS and GRFS reached $67 \%$ and $51 \%$, respectively. Overall, this compared very favorably with the results obtained with the standard of care RIC regimen used in France, the FB2A2 regimen [4-9]. This also confirmed our previous data for AML patients in CR where the 2-year OS and LFS for FB2A2
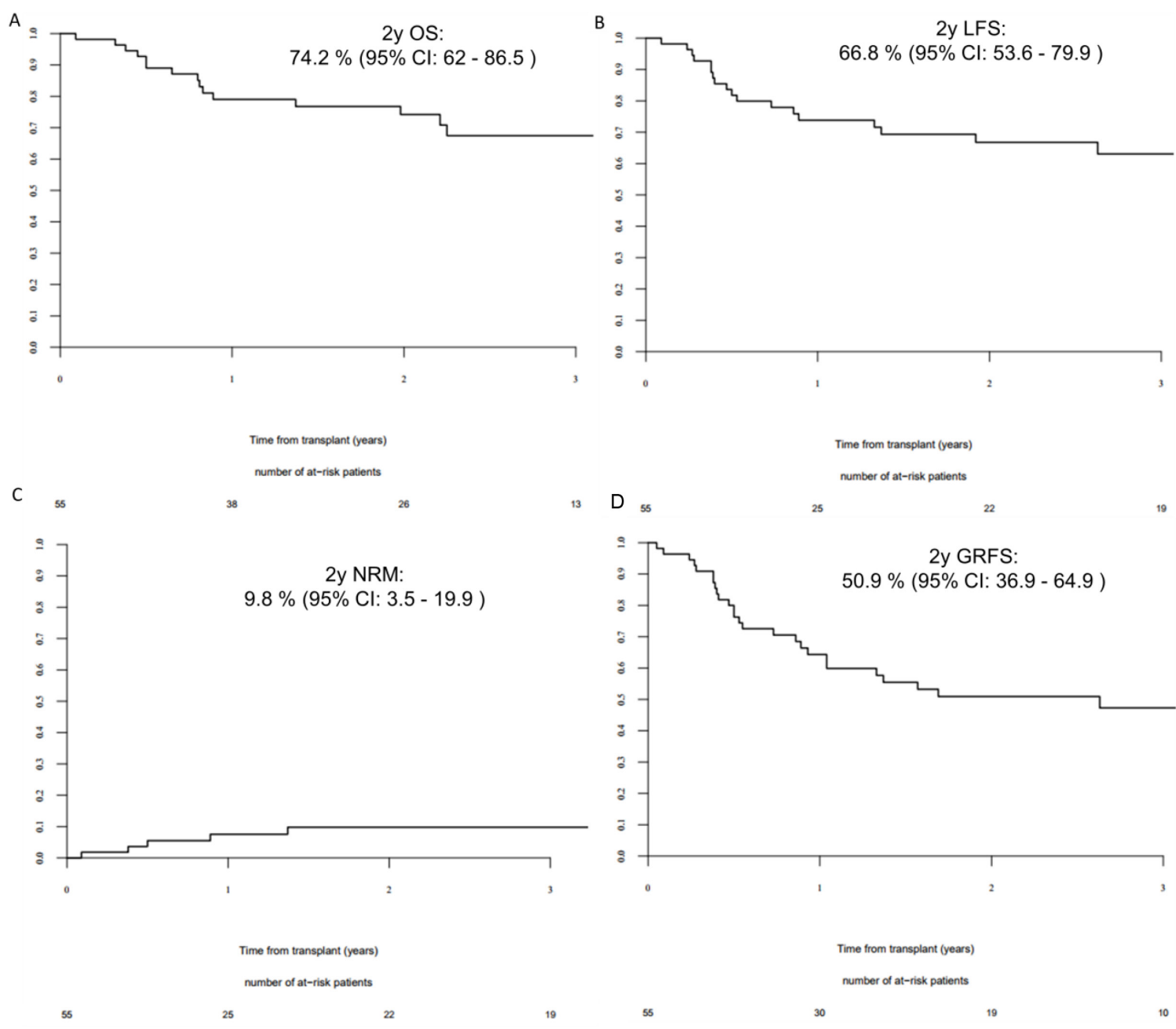

Figure 1: 2 year outcomes for AML patients in complete remission at transplant. (A) 2-year overall survival for acute myeloid leukemia (AML) patient in complete remission (CR); (B) 2-year leukemia free survival for AML patients in CR; (C) 2-year nonrelapse mortality for AML patients in CR; (D) 2-year GVHD-free/relapse-free survival for AML patient in CR. 
Table 2: Comparison of 2-year outcomes between CloB2A1 and CloB2A2 sub-groups

\begin{tabular}{|c|c|c|c|c|c|c|c|c|c|}
\hline & & $\begin{array}{l}\text { Relapse } \\
\text { incidence }\end{array}$ & NRM & LFS & OS & GRFS & $\begin{array}{c}\text { CI of 100-day } \\
\text { grade II-IV } \\
\text { acute GVHD }\end{array}$ & $\begin{array}{l}\text { CI of } 100- \\
\text { day grade } \\
\text { III-IV acute } \\
\text { GVHD }\end{array}$ & $\begin{array}{c}\text { CI of } \\
\text { extensive } \\
\text { chronic } \\
\text { GVHD }\end{array}$ \\
\hline \multirow{3}{*}{$\begin{array}{l}\text { All } \\
\text { patients }\end{array}$} & CloB2A1 & $\begin{array}{c}28.8 \% \\
{[15.1-44]}\end{array}$ & $\begin{array}{c}10.5 \% \\
{[3.2-22.7]}\end{array}$ & $\begin{array}{c}60.8 \% \\
{[44.9-76.6]}\end{array}$ & $\begin{array}{c}61.2 \% \\
{[43.8-78.6]}\end{array}$ & $\begin{array}{c}45 \% \\
{[27.9-62]}\end{array}$ & $\begin{array}{c}22 \% \\
{[10.7-35.7]}\end{array}$ & $\begin{array}{c}7.3 \% \\
{[1.9-18]}\end{array}$ & $\begin{array}{c}6.1 \% \\
{[1-18.2]}\end{array}$ \\
\hline & CloB2A2 & $\begin{array}{c}26.3 \% \\
{[14-40.3]}\end{array}$ & $\begin{array}{c}19 \% \\
{[8.8-32.2]}\end{array}$ & $\begin{array}{c}54.7 \% \\
{[39.6-69.7]}\end{array}$ & $\begin{array}{c}65.1 \% \\
{[50.9-79.4]}\end{array}$ & $\begin{array}{c}41.7 \% \\
{[27-56.5]}\end{array}$ & $\begin{array}{c}18.6 \% \\
{[8.6-31.5]}\end{array}$ & $\begin{array}{c}7 \% \\
{[1.8-17.2]}\end{array}$ & $\begin{array}{c}12 \% \\
{[4.3-24.1]}\end{array}$ \\
\hline & $p$-value & 0.51 & 0.55 & 0.93 & 0.94 & 0.97 & 0.44 & 0.99 & 0.43 \\
\hline \multirow{3}{*}{$\begin{array}{l}\text { AML in } \\
\text { RC }\end{array}$} & CloB2A1 & $\begin{array}{c}25.6 \% \\
{[10.8-43.6]}\end{array}$ & $\begin{array}{c}4.2 \% \\
{[0.3-18.1]}\end{array}$ & $\begin{array}{c}70.2 \% \\
{[52.4-88]}\end{array}$ & $\begin{array}{c}74.4 \% \\
{[55.7-93.1]}\end{array}$ & $\begin{array}{c}47.8 \% \\
{[27.2-68.4]}\end{array}$ & $\begin{array}{c}13.3 \% \\
{[4.1-28.1]}\end{array}$ & $0 \%$ & $\begin{array}{c}8.6 \% \\
{[1.3-24.7]}\end{array}$ \\
\hline & CloB2A2 & $\begin{array}{c}20 \% \\
{[7-37.7]}\end{array}$ & $\begin{array}{c}16 \% \\
{[4.8-33]}\end{array}$ & $\begin{array}{c}64 \% \\
{[45.2-82.8]}\end{array}$ & $\begin{array}{c}72 \% \\
{[54.4-89.6]}\end{array}$ & $\begin{array}{c}52 \% \\
{[32.4-71.6]}\end{array}$ & $\begin{array}{c}20 \% \\
{[7.1-37.6]}\end{array}$ & $\begin{array}{c}4 \% \\
{[0.3-17.4]}\end{array}$ & $\begin{array}{c}12 \% \\
{[2.9-28.2]}\end{array}$ \\
\hline & $p$-value & 0.30 & 0.14 & 0.97 & 0.50 & 0.86 & 0.95 & 0.27 & 0.72 \\
\hline
\end{tabular}

Abbreviations: AML: acute myeloid leukemia, CR: complete remission, GRFS: GVHD-free/relapse-free survival, LFS: leukemia free survival, NRM: non-relapse mortality, OS: overall survival, CI: cumulative incidence.

patients were only $38 \%$ and $38 \%$, respectively, while it was $79.2 \%$ and $70.8 \%$ for the CloB2A2 group [20].

GRFS, a new composite end-point reflecting the quality of life of patients after transplant, has been poorly studied so far in the context of RIC setting. Here again, our results compared favorably with those published, as it is estimated that only approximately one-quarter of adult patients transplanted for malignant disease survived without at least 1 of the following major complications, grade 3-4 acute GVHD, chronic GVHD requiring systemic treatment, relapse, or death, during the first 12 months after HCT. Indeed, in the study by Holtan and colleagues, the first to consider this outcome after transplant, the estimated 1 -year GRFS was only $26 \%$ after RIC [22]. A recent EBMT study, including more than 20000 cases of AML in CR1 or CR2, showed a GRFS of $40 \%$ at 3 years after both myeloablative and RIC regimens [23].

As recognized years ago for both myeloablative and RIC regimens [24], including fludarabine/busulfan based RIC regimens $[8,20]$, status at transplant remains the most important factor predicting survival for patients in our series. As such, all effort should be targeted to inducing CR before transplant, keeping in mind that CR1 and CR2 cases achieved similar survivals here. This highlights the potential impact of the depth of the response before the transplant, even in CR2. Measurable residual disease (MRD) for AML may have a decisive role in risk-stratification and prediction of outcomes after transplant to guide the intensity and the quality, in terms of anti-leukemic activity, of the conditioning regimen. For example, pre allo-SCT molecular MRD evaluation of NPM1 mutation was shown to be a powerful predictor of post allo-SCT outcomes in AML undergoing allo-SCT in cytologic CR [25]. Other data suggested the same for MRD evaluation of WT1 expression before transplant [26]. In cases with no cytogenetic or molecular markers associated with the AML, MRD evaluated by flow cytometry can also be an effective tool to predict relapse risk after transplant [27, 28]. As suggested before, maybe it is time to move towards a MRD-based definition of CR [29], especially now that the establishment of a consensus on measurement and application of MRD in AML has been achieved [30].

Compared to our previous report, one of the most original results here is the impact of decreasing the duration of ATG treatment to one day instead of two. It has been shown that reducing the dose of ATG, albeit possibly associated with less relapse [31], may be more damaging in terms of severe acute or chronic GVHD in the setting of fludarabine/busulfan-based RIC regimen [32, 33]. This seems not to be the same for clofarabine/busulfan-based RIC regimen as we observed similar survivals and GVHD incidences using $\mathrm{CloB} 2 \mathrm{~A} 2$ or $\mathrm{CloB} 2 \mathrm{~A} 1$, suggesting also that only one day of ATG is sufficient in this context.

As clofarabine seems to have a high anti-leukemic activity, its use for alternative transplant as part of the conditioning regimen may be also appropriate. Although scanty data exist for cord blood transplant [34], sequential approaches of debulking with clofarabine/cytosine arabinoside followed by the conditioning regimen have been recently published with encouraging results for refractory AML $[35,36]$. We have also recently reported our experience of a "Clo-Baltimore" RIC regimen for myeloid malignancies where fludarabine is replaced by clofarabine as part of a standard Baltimore regimen. The results of this approach in 36 patients showed 18-month OS and DFS of $72 \%+7.5 \%$, and $63.8+8 \%$, respectively, and a GRFS of $52.6+8 \%$ [37].

Finally, the question on how to improve our results by post-transplant strategies to avoid relapse is a real issue. FMS-like tyrosine kinase 3 inhibitors for FLT3ITD-positive AML [38] or prophylactic azacitidine and donor lymphocyte infusions [39] after allo-SCT may become also a new standard of care in the future for both clofarabine/fludarabine-busulfan based RIC regimen allo-SCT. 

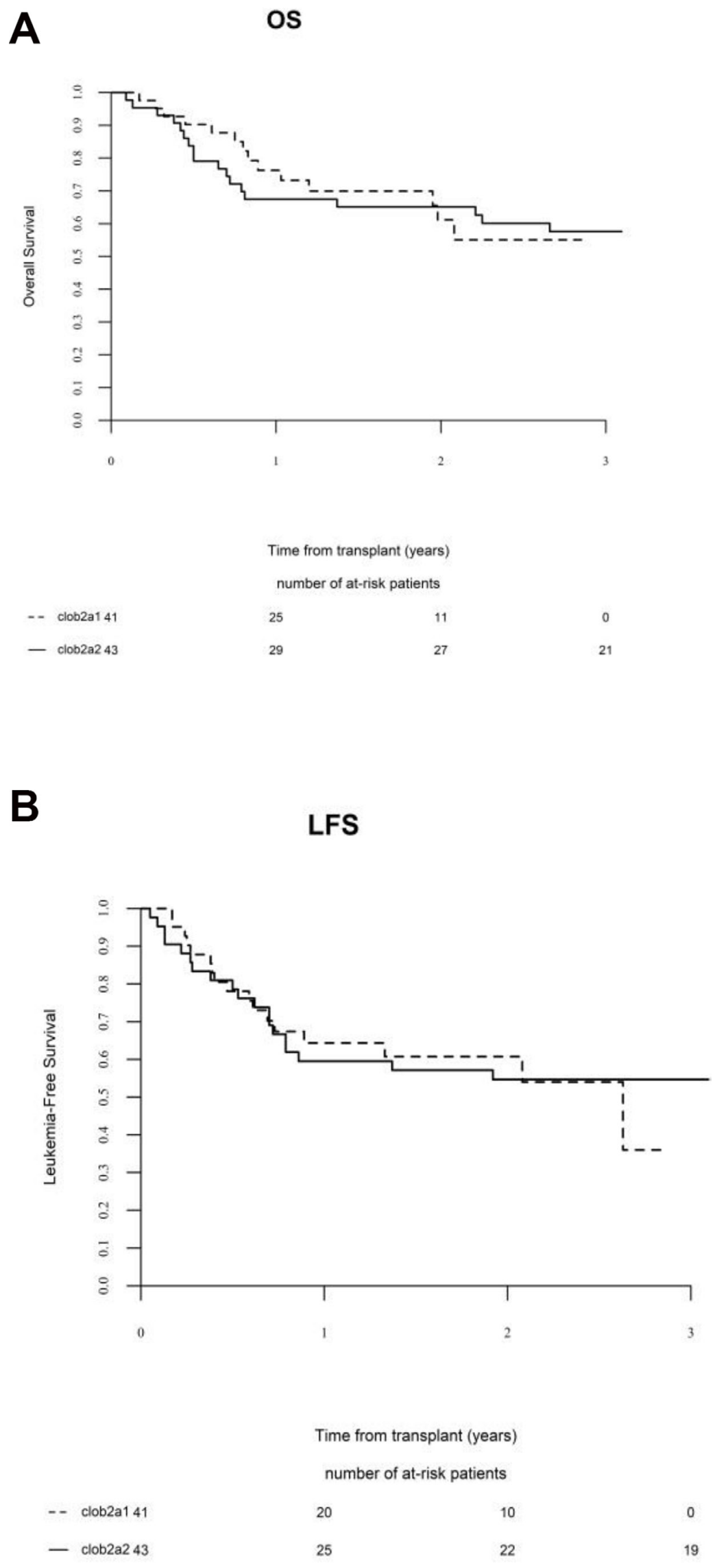

Figure 2: Comparison of (A) overall survival (OS) and (B) leukemia-free survival (LFS) between CloB2A1 and CloB2A2 sub-groups. 
In conclusion, CloB2A2/A1 $\mathrm{RIC}$ regimen provide very good results for AML patients allografted in CR and should be retained as a new RIC platform for these patients. Prospective studies are definitively needed to compare CloB2 vs FB2 RIC regimens.

\section{MATERIALS AND METHODS}

\section{Eligibility criteria and study design}

This was a retrospective study conducted on behalf of the Société Francophone de Greffe de Moelle et de Thérapie Cellulaire (SFGMTC), including all adults $(\geq 18$ years old) who received a clofarabine/busulfan based RIC allo-SCT for myeloid malignancies (AML, MDS, myeloproliferative syndrome (MPS)) and reported within the SFGM-TC registry. Data were obtained through PROMISE, an internet-based system shared by all European transplantation centers. All patients gave informed consent for collection of their personal data in this data base.

\section{Conditioning regimen}

The RIC regimen consisted of clofarabine $30 \mathrm{mg} / \mathrm{m}^{2} /$ day for 4 to 5 days (Clo), busulfan $3.2 \mathrm{mg} / \mathrm{kg}$ / day for 2 days (B2) and rabbit anti-thymocyte globulin (A) $2.5 \mathrm{mg} / \mathrm{kg} /$ day for 1 or 2 days (A1 or A2). CloB2A2 was initially used as the conditioning platform, while since 2014 some centers have used CloB2A1 in order to try to decrease relapse and infections, and thus improve on the results of the $\mathrm{CloB} 2 \mathrm{~A} 2$ patients [4].

\section{Statistical analyses}

The clinical outcomes studied were overall survival (OS), leukemia-free survival (LFS), relapse incidence (RI) and non-relapse mortality (NRM). OS was defined as the time from day 0 of allo-SCT to death or last follow-up for survivors. LFS was defined as time from day 0 of allo-SCT to time without evidence of relapse or disease progression. Relapse was defined as any event related to re-occurrence of the disease. NRM was defined as death from any cause without previous relapse or progression. Probabilities of OS and LFS were calculated using the log-rank test and Kaplan-Meier graphical representation. Cumulative incidence functions (CIF) [40] were used to estimate RI and NRM in a competing risk setting. In order to study acute and chronic graft versus host disease (GVHD), we considered death and relapse as competing events. Acute and chronic GVHD were diagnosed and graded according to standard criteria [41, 42]. The GVHD-free/relapsefree survival (GRFS), defined as alive with no previous grade III-IV aGvHD, no extensive chronic GvHD and no relapse [22, 23], was also studied. Survival probabilities are presented as percentages and $95 \%$ confidence intervals $(95 \% \mathrm{CI})$.
Univariate analyses were performed using the log rank test for OS and LFS and the Gray test for CIF. Characteristics considered for univariate analysis were the conditioning regimen (CloB2A2 vs CloB2A1), recipient gender (male vs female) and age $(<$ or $\geq$ median, continuous); years of transplant ( $<$ or $\geq$ median), disease (AML vs MDS/MPS), disease status at transplant (first complete remission (CR1) vs second CR (CR2) vs active disease), type of donors (sibling vs matched unrelated donor (MUD)), donor gender (male vs female) and age $(<$ or $\geq$ median), gender matching (female donor for male recipient vs others), recipient and donor CMV status (+ vs -), GVHD prophylaxis (cyclosporine vs cyclosporine + mycophenolate mofetil) and dose of clofarabine $\left(120 \mathrm{mg} / \mathrm{m}^{2} \mathrm{vs} \geq 150 \mathrm{mg} /\right.$ $\mathrm{m}^{2}$ ). Main outcomes were also compared between CloB2A2 vs CloB2A1 cases, considering only AML patients in CR.

Multivariate analyses were performed using the Cox proportional-hazard model. Factors significantly associated with the outcome in univariate analysis and factors known to influence outcomes were included in the multivariate analysis.

All tests were two-sided and $P$ values $<0.05$ were considered as indicating a statistically significant association. Analyses were performed using the $\mathrm{R}$ statistical software version 3.2.3 (available online at http:// www.R-project.org).

\section{Author contributions}

A.L B and P.C designed, performed, coordinated the research, analyzed, interpreted the data, and wrote the manuscript. M.L performed the statistical analyses and provided the figures. S.M, R.P d L, J.H.B, P.C, S.F, H.L W, K.B, D.B, M.T.R, T.G and M.M contributed data and commented on the manuscript.

\section{ACKNOWLEDGMENTS}

We wish to thank all investigators and data managers for their dedicated patient care.

\section{Ethics approval}

All patients gave informed consent for collection of their personal data in this data base.

The study has been approved by the ethic comitte of STGM-TC.

\section{Availability of data and material}

All data generated or analysed during this study are included in this published article.

\section{CONFLICTS OF INTEREST}

The authors declare no conflicts of interest. 


\section{FUNDING}

Not applicable.

\section{REFERENCES}

1. Slavin S, Nagler A, Naparstek E, Kapelushnik Y, Aker M, Cividalli G, Varadi G, Kirschbaum M, Ackerstein A, Samuel S, Amar A, Brautbar C, Ben-Tal O, et al. Nonmyeloablative stem cell transplantation and cell therapy as an alternative to conventional bone marrow transplantation with lethal cytoreduction for the treatment of malignant hematologic diseases. Blood. 1998; 91:756-63.

2. McSweeney PA, Niederwieser D, Shizuru JA, Sandmaier BM, Molina AJ, Maloney DG, Chauncey TR, Gooley TA, Hegenbart U, Nash RA, Radich J, Wagner JL, Minor S, et al. Hematopoietic cell transplantation in older patients with hematologic malignancies: replacing high-dose cytotoxic therapy with graft-versus-tumor effects. Blood. 2001; 97:3390-400.

3. Giralt S, Estey E, Albitar M, van Besien K, Rondon G, Anderlini P, O'Brien S, Khouri I, Gajewski J, Mehra R, Claxton D, Andersson B, Beran M, et al. Engraftment of allogeneic hematopoietic progenitor cells with purine analog-containing chemotherapy: harnessing graft-versusleukemia without myeloablative therapy. Blood. 1997; 89:4531-6.

4. Michallet $\mathrm{M}, \mathrm{Le} \mathrm{QH}$, Mohty $\mathrm{M}$, Prebet $\mathrm{T}$, Nicolini $\mathrm{F}$, Boiron JM, Esperou AH, Attal M, Milpied N, Lioure B, Bordigoni P, Yakoub-Agha I, Bourhis JH, et al. Predictive factors for outcomes after reduced intensity conditioning hematopoietic stem cell transplantation for hematological malignancies: a 10-year retrospective analysis from the Société Française de Greffe de Moelle et de Thérapie Cellulaire. Exp Hematol. 2008; 36:535-44.

5. Blaise D, Tabrizi R, Boher JM, Le Corroller-Soriano AG, Bay JO, Fequeux N, Boiron JM, Furst S, Castagna L, Chabannon C, Boyer-Chammard A, Milpied N, LabussièreWallet $\mathrm{H}$, et al. Randomized study of 2 reduced-intensity conditioning strategies for human leukocyte antigenmatched, related allogeneic peripheral blood stem cell transplantation: prospective clinical and socioeconomic evaluation. Cancer. 2013; 119:602-11.

6. Lioure B, Bene MC, Pigneux A, Huynh A, Chevallier C, Fequeux N, Blaise D, Witz B, Delain M, Cornillon J, Luquet I, Blanchet O, Cornillet-Lefebvre P, et al. Early matched sibling hematopoietic cell transplantation for adult AML in first remission using an age adapted strategy: longterm results of a prospective GOELAMS study. Blood. 2012; 119:2943-8.

7. Le Bourgeois A, Lestang E, Guillaume T, Delaunay J, Ayari S, Blin N, Clavert A, Tessoulin B, Dubruille V, Mahe B, Roland V, Gastinne T, Le Gouill S, et al. Prognostic impact of immune status and hematopoietic recovery before and after fludarabine, IV busulfan and antithymocyte globulins
(FB2 regimen) reduced-intensity conditioning regimen (RIC) allogeneic stem cell transplantation (allo-SCT). Eur J Haematol. 2013; 90:177-86.

8. Oudin C, Chevallier P, Furst S, Guillaume T, El Cheikh J, Delaunay J, Castagna L, Faucher C, Granata A, Devillier $\mathrm{R}$, Chabannon C, Esterni B, Vey N, et al. Reduced-toxicity conditioning prior to allogeneic stem cell transplantation improves outcome in patients with myeloid malignancies. Haematologica. 2014; 99:1762-1768.

9. Rubio MT, Labopin M, Blaise D, Socié G, Contreras RR, Chevallier P, Sanz MA, Vigouroux S, Huynh A, Shimono A, Bulabois CE, Caminos N, Lopez-Corral L, et al. The impact of graft-versus-host disease prophylaxis in reducedintensity conditioning allogeneic stem cell transplant in acute myeloid leukemia: a study from the Acute Leukemia Working Party of the European Group for Blood and Marrow Transplantation. Haematologica. 2015; 100:683-689.

10. Mohty M, Malard F, Blaise D, Milpied N, Frust S, Tabrizi R, Guillaume T, Vigouroux S, El-Cheikh J, Delaunay J, Le Gouill S, Moreau P, Labopin M, et al. Reduced-toxicity conditioning with fludarabine, once-daily intravenous busulfan, and antithymocyte globulins prior to allogeneic stem cell transplantation: results of a multicenter prospective phase 2 trial. Cancer. 2015; 121:562-9.

11. Kharfan-Dabaja MA, Labopin M, Bazarbachi A, Hamladji RM, Blaise D, Socié G, Lioure B, Bermudez A, LopezCorral L, Or R, Arcese W, Fequeux N, Nagler A, et al. Comparing i.v. BU dose intensity between two regimens (FB2 vs FB4) for allogeneic HCT for AML in CR1: a report from the Acute Leukemia Working Party of EBMT. Bone Marrow Transplant. 2014; 49:1170-5.

12. Kharfan-Dabaja MA, Labopin M, Bazarbachi A, Socié G, Kroeger N, Blaise D, Veelken H, Bermudez A, Or R, Lioure B, Beelen D, Fequeux N, Hamladji RM, et al. Higher busulfan dose intensity appears to improve leukemia-free and overall survival in AML allografted in CR2: An analysis from the Acute Leukemia Working Party of the European Group for Blood and Marrow Transplantation. Leuk Res. 2015; 39:933-7.

13. Becker PS, Kantarjian HM, Appelbaum FR, Storer B, Pierce S, Shan J, Faderl S, Estey EH. Retrospective comparison of clofarabine versus fludarabine in combination with high-dose cytarabine with or without granulocyte colonystimulating factor as salvage therapies for acute myeloid leukemia. Haematologica. 2013; 98:114-118.

14. Molteni A, Riva M, Ravano E, Marbello L, Mancini V, Grillo G, Zucchetti E, Greco R, Cairoli R. Clofarabine based chemotharapy as a bridge to transplant in the setting of refractory or relapsed acute myeloid leukemia, after at least one previous unsuccessful salvage treatment containing fludarabine: a single institution experience. Int J Hematol. 2017; 105:769-776.

15. Thomas X, de Botton S, Chevret S, Caillot D, Raffoux E, Lemasle E, Marolleau JP, Berthon C, Pigneux A, Vey N, Reman O, Simon M, Recher C, et al. Randomized Phase 
II Study of Clofarabine-Based Consolidation for Younger Adults With Acute Myeloid Leukemia in First Remission. J Clin Oncol. 2017; 35:1223-1230.

16. Jeha S, Gandhi V, Chan KW, McDonald L, Ramirez I, Madden R, Rytting M, Brandt M, Keating M, Plunkett W, Kantarjan H. Clofarabine, a novel nucleoside analog is active in pediatric patients with advanced leukemia. Blood. 2004; 103:784-789.

17. Jeha S, Gaynon PS, Razzouk BI, Franklin J, Kadota R, Shen V, Luchtman-Jones L, Rytting M, Bomgaars LR, Rheingold S, Ritchey K, Albano E, Arceci RJ, et al. Phase II study of clofarabine in pediatric patients with refractory or relapsed acute lymphoblastic leukemia. J Clin Oncol. 2006; 24: 1917-1923.

18. Chevallier P, Labopin M, Socié G, Tabrizi R, Frust S, Lioure B, Guillaume T, Delaunay J, de La Tour RP, Vigouroux S, El-Cheikh J, Blaise D, Michallet M, et al. Result from clofarabine-busulfan-containing, reduced-toxicity conditioning regimen prior to allogeneic stem cell transplantation: the phase 2 prospective CLORIC trial. Haematologica. 2014; 99:1486-91.

19. Kebriaei P, Bassett R, Lyons G, Valdez B, Ledesma C, Rondon G, Oran B, Ciurea S, Alousi A, Popat U, Patel $\mathrm{K}$, Ahmed S, Olson A, et al. Clofarabine plus busulfan is an effective conditioning regimen for allogeneic hematopoietic stem cell transplantation in patients with acute lymphoblastic leukemia: long-term study results. Biol Blood Marrow Transplant 2017; 23:285-292.

20. Chevallier P, Labopin M, Peffault De Latour R, Lioure B, Bulabois CE, Huynh A, Blaise D, Turlure P, Daguindau E, Maillard N, Yakoub-Agha I, Guillerm G, Delage J, et al. Clofarabine versus Fludarabine-based reduced-intensity conditioning regimen prior allogeneic transplantation in adult with AML/MDS. Cancer Med. 2016; 5:3068-3076.

21. Döhner H, Estey EH, Amadori S, Appelbaum FR, Buchner T, Burnett AK, Dombret H, Fenaux P, Grimwade D, Larson RA, Lo-Coco F, Naoe T, Niederwieser D, et al. Diagnosis and management of acute myeloid leukemia in adults: recommendations from an international expert panel, on behalf of the European LeukemiaNet. Blood. 2010; 115:453-74.

22. Holtan SG, DeFor TE, Lazaryan A, Bejanyan N, Arora M, Brunstein CG, Blazar BR, MacMillan ML, Weisdorf DJ. Composite end point of graft-versus-host disease-free, relapse-free survival after allogeneic hematopoietic cell transplantation. Blood. 2015; 125:1333-8.

23. Ruggeri A, Labopin M, Ciceri F, Mohty M, Nagler A. Definition of GvHD-free, relapse-free survival for registrybased studies: an ALWP-EBMT analysis on patients with AML in remission. Bone Marrow Transplant. 2016; 51:610-1.

24. Aoudjhane M, Labopin M, Gorin NC, Shimoni A, Ruutu T, Kolb HJ, Frassoni F, Boiron JM, Yin JL, Finke J, Shouten H, Blaise D, Falda M, et al. Comparative outcome of reduced intensity and myeloablative conditioning regimen in
HLA identical sibling allogeneic haematopoietic stem cell transplantation for patients older than 50 years of age with acute myeloblastic leukaemia: a retrospective survey from the Acute Leukemia Working Party (ALWP) of the European group for Blood and Marrow Transplantation (EBMT). Leukemia. 2005; 19:2304-2312.

25. Balsat M, Renneville A, Thomas X, de Botton S, Caillot D, Marceau A, Lemasle E, Marolleau JP, Nibourel O, Berthon C, Raffoux E, Pigneux A, Rodriquez C, et al. Postinduction Minimal Residual Disease Predicts Outcome and Benefit From Allogeneic Stem Cell Transplantation in Acute Myeloid Leukemia With NPM1 Mutation: A Study by the Acute Leukemia French Association Group. J Clin Oncol. 2017; 35:185-193.

26. Candoni A, De Marchi F, Zannier ME, Lazzarotto D, Filì C, Dubbini MV, Rabassi N, Toffoletti E, Lau BW, Fanin R. High prognostic value of pre-allogeneic stem cell transplantation minimal residual disease detection by WT1 gene expression in AML transplanted in cytologic complete remission. Leuk Res. 2017; 63:22-27.

27. Walter RB, Gyurkocza B, Storer BE, Godwin CD, Pagel JM, Buckley SA, Sorror ML, Wood BL, Storb R, Appelbaum FR, Sandmair BM. Comparison of minimal residual disease as outcome predictor for AML patients in first complete remission undergoing myeloablative or nonmyeloablative allogeneic hematopoietic cell transplantation. Leukemia. 2015; 29:137-44.

28. Lacombe F, Campos L, Allou K, Arnoulet C, Delabarthe A, Dumezy F, Feuillard J, Geneviève F, Guérin E, Guy J, Jouault H, Lepelley P, Maynadié M, et al. Prognostic value of multicenter flow cytometry harmonized assessment of minimal residual disease in acute myeloblastic leukemia. Hematol Oncol. 2018; 36:422-428.

29. Araki D, Wood BL, Othus M, Radich JP, Halpern AB, Zhou Y, Mielcarek M, Estey EH, Appelbaum FR, Walter RB. Allogeneic Hematopoietic Cell Transplantation for Acute Myeloid Leukemia: Time to Move Toward a Minimal Residual Disease-Based Definition of Complete Remission? J Clin Oncol. 2016; 34:329-36.

30. Schuurhuis GJ, Heuser M, Freeman S, Béné MC, Buccisano F, Cloos J, Grimwade D, Haferlach T, Hills RK, Hourigan CS, Jorgensen JL, Kern W, Lacombe F, et al. Minimal/ measurable residual disease in AML: a consensus document from the European LeukemiaNet MRD Working Party. Blood. 2018; 131:1275-1291.

31. Mohty M, Bay JO, Faucher C, Choufi B, Bilger K Tournilhac O, Vey N, Stoppa AM, Coso D, Chabannon C, Viens P, Maraninchi D, Blaise D. Graft-versus-host disease following allogeneic transplantation from HLA-identical sibling with antithymocyte globulin-based reduced-intensity preparative regimen. Blood. 2003; 102:470-6.

32. Devillier R, Crocchiolo R, Castagna L, Furst S, El Cheikh J, Faucher C, Prebet T, Etienne A, Chabannon C, Vey N, Esterni B, Blaise D. The increase from 2.5 to $5 \mathrm{mg} / \mathrm{kg}$ of rabbit anti-thymocyte-globulin dose in reduced intensity conditioning reduces acute and chronic GVHD for patients 
with myeloid malignancies undergoing allo-SCT. Bone Marrow Transplant. 2012; 47:639-645.

33. Crocchiolo R, Esterni B, Castagna L, Furst S, El-Cheikh J, Devillier R, Granata A, Oudin C, Calmels B, Chabannon C, Bouabdallah R, Vey N, Blaise D. Two days of antithymocyte globulin are associated with a reduced incidence of acute and chronic graft-versus-host disease in reduced-intensity conditioning transplantation for hematologic diseases. Cancer. 2013; 119:986-92.

34. Mehta RS, Di Stasi A, Andersson BS, Nieto Y, Jones R, de Lima M, Hosing C, Popat U, Kebriaei P, Oran B, Alousi A, Rezvani K, Qazilbash M, et al. The development of a myeloablative, reduced-toxicity, conditioning regimen for cord blood transplantation. Clin Lymphoma Myeloma Leuk. 2014; 14:e1-5.

35. Tischer J, Stemmler HJ, Engel N, Hubmann M, Fritsch S, Prevalsek D, Schulz C, Zoellner AK, Bücklei n V, Hill W, Ledderose G, Hausmann A. Feasibility of clofarabine cytoreduction followed by haploidentical hematopoietic stem cell transplantation in patients with relapsed or refractory advanced acute leukemia. Ann Hematol. 2013; 92:1379-88.

36. Rakszawski K, Miki K, Claxton D, Wagner H, Shike H, Mineishi S, Naik S. Clofarabine followed by haploidentical stem cell transplant using fludarabine, busulfan, and totalbody irradiation with post-transplant cyclophosphamide in non-remission AML. Int J Hematol. 2018; 108:348-350. https://doi.org/10.1007/s12185-018-2431-5.

37. Chevallier P, Peterlin P, Garnier A, Le Bourgeois A, Mahé B, Dubruille V, Blin N, Touzeau C, Gastinne T, Lok A, Le Bris Y, Béné MC, Le Gouill S, et al. Clofarabine-Based Reduced Intensity Conditioning Regimen with PostTransplant Cyclophosphamide and Peripheral Stem Cell
Graft in Adults with Myeloid Malignancies: Results of the Clo-Baltimore Regimen. Blood. 2017; 130:1964; 2017 ASH meeting.

38. Battipaglia G, Ruggeri A, Massoud R, El Cheikh J, Jestin M, Antar A, Ahmed SO, Rasheed W, Shaheen M, Belhocine R, Brissot E, Dulery R, Eder S, et al. Efficacy and feasibility of sorafenib as a maintenance agent after allogeneic hematopoietic stem cell transplantation for Fmslike tyrosine kinase 3-mutated acute myeloid leukemia. Cancer. 2017; 123:2867-2874.

39. Guillaume T, Yakoub-Agha I, Tabrizi R, Borel C, Chevallier P, Magro L, Vigouroux S, Peterlin A, Garnier A, Rubio MT, Huynh A, Milpied N, Moreau P, Mohty M. Prospective Phase II Study of Prophylactic Azacitidine and Donor Lymphocyte Infusions Following Allogeneic Hematopoietic Stem Cell Transplantation for High Risk Acute Myeloid Leukemia and Myelodysplastic Syndrome. Blood. 2016; 128:1162; 2016 ASH meeting.

40. Gooley TA, Leisenring W, Crowley J, Storer BE. Estimation of failure probabilities in the presence of competing risks: new representations of old estimators. Stat Med. 1999; 18:695-706.

41. Glucksberg H, Storb R, Fefer A, Buckner CD, Neiman PE, Clift RA, Lerner KG, Thomas ED. Clinical manifestations of graft-versus-host disease in human recipients of marrow from HLA-matched sibling donors. Transplantation. 1974; 18:295-304.

42. Shulman H, Sullivan KM, Weiden PL, McDonald GB, Striker GE, Sale GE, Hackman R, Tsoi MS, Stord R, Thomas ED. Chronic graft-versus-host syndrome in man. A long-term clinicopathologic study of 20 Seattle patients. Am J Med. 1980; 69:204-17. 